\title{
THE CASTLE IN THE GRAND DUCHY OF LITHUANIA: HISTORIOGRAPHY, SEARCH FOR DEFINITIONS, RESEARCH MODEL
}

\author{
Vytautas Volungevičius
}

ABSTRACT This article aims to reinterpret the castle in the Grand Duchy of Lithuania, at the same time as evaluating the state of historiography and trends in terminology used in historical sources. Historiographical problems are defined from a comparative perspective. The author emphasises interpretational issues which refer to the word 'castle' in different languages used in different sources. The newly formulated definition of the castle as a changing historical phenomenon expands the concept of the castle. This signifies that the castle was not a static subject. The castle is therefore perceived as an integral part of the historical social reality. This idea is based on certain material and socio-political assumptions.

In theory, the castle is understood as an object of structures and social history, research into which should embrace different aspects of social reality: judicial, military-defensive, political-representational, economichousehold. The proposed quaternary model of the research (1. The castle and its internal structure; 2. The castle and its external structure; 3. The particularity of the castles of the Grand Duchy of Lithuania; 4. The dispersion of castles in the territory of the state) presupposes the multi-layered perspective of the phenomenon of the castle, which guides from fact to process, from object to structure. The article states that the castle as a long time phenomenon cannot be perceived and interpreted separately from simultaneous socio-political circumstances which were formed by the local society.

In a conference devoted to the historiography of Soviet Lithuania, A. Bumblauskas remarked during the discussion that R. Žiugžda as early as 1982 had said that one cannot take an interest in castles, because it was 'a unified stream' 1 . That, even though in a featureless manner, unambiguously reflects the situation of that time. Only

${ }^{1}$ Lietuvos sovietine istoriografija. Teoriniai ir ideologiniai kontekstai, comp. by A. Bumblauskas, N. Šepetys (Vilnius, 1999), p. 253. About 'the unified stream' and its connotations, see A. Švedas, Matricos nelaisveje: Sovietmečio lietuviu istoriografija (1944-1985) (Vilnius, 2009). 
the open question remains: to what extent was this a consciously expressed position, keeping in mind the social aspect of possible problems, touching on the complicated nature of old Lithuanian society in the feudal era, the nature and the features of the local structure? In the Soviet period, historical, archaeological and architectural studies about Lithuania's castles appeared ${ }^{2}$, but all of them were devoted to individual castles in Lithuania, they made a weak link between the architectural and political-social aspects of the research, and thus did not formulate the problem of the castle as an integral phenomenon of the Grand Duchy of Lithuania (GDL).

Studies of castles in postwar Europe developed in a totally different way. The words of the famous French medievalist G. Duby, starting the chapter of the book devoted to the history of French culture, 'Castles and Authority': 'the new social structure in any case is forming around the fortified building - the castle' ${ }^{3}$, express their direction well. Here Duby continues the historical story about space and the social environment working in it, understanding them as closely related to one another, things conditioning one another.

This article attempts to look at the castle as an object of structures and social history, in other words, as an integral part of social reality. It consists of four parts:

- The first discusses research so far on the castle and the historiography of the prevailing concept of the castle.

- The second analyses the terminology of the multilingual sources of the GDL in the 13th to 16th centuries, and from a comparative perspective attempts to interpret in a new way the phenomenon of the castle and its genesis in Lithuania.

- The third attempts to justify the theoretical approaches of social and structural history in the study of the castle, and to mark out the main aspects of investigations into the castle phenomenon.

- The fourth formulates a model for research into the castle phenomenon, and discusses the potential perspectives of the research.

The chronological frames of the work include the period from the 14th century to the first half of the 16th century. It should be

${ }^{2}$ Lietuvos pilys (Vilnius, 1971); about individual castles, see E. Budreika, Vilniaus pilis (Vilnius, 1977); J. Jurginis, Medininku pilis (Vilnius, 1984); N. Kitkauskas, Vilniaus pilys: statyba ir architektūra (Vilnius, 1989).

3 G. Duby, R. Mandrou, Historia kultury francuskiej wiek $X-X X$ (Warsaw, 1965), p. 40; see also G. Duby, Katedru laikai, menas ir visuomene 980-1420 (Vilnius, 2004), p. 54. 
emphasised that it is impossible to establish a strict chronological definition, with specific boundary markers, of the start and end, because the object of study must be understood as a process rather than an individual event or fact. The choice of the chronological frames is motivated by processes that occurred from the 14th century to the first half of the 16th century in the Grand Duchy of Lithuania:

- The 14th-century formation of the GDL as an early feudal monarchy, which marks the emergence of new political and social organisations.

- At the juncture of the 13th and 14th centuries in Lithuania propria and in Žemaitija, structures of castles are attributable with the entrenchment of one ruling dynasty.

- At the end of the 14 th century the phenomenon of homogial oaths as the start of the transformation of the old organisational models of Ruthenian territories and principalities.

- At the end of the 14th century the decline/transformation of wooden castles in Lithuania propria.

- The rise of the GDL's nobility in the first half of the 16th century and the associated emergence of castles in their lands.

- The technological changes (artillery) in the first half of the 16th century, as well as the changing architectonics, function and purpose of castles: from castle to bastion castles and palaces.

- The 14 th to 16 th centuries, beginning with the steady expansion of the GDL into Ruthenian territories and ending with the Union of Lublin in 1569, may be understood as a relatively territorial development of an integral historical individual.

- In the 14th to 16 th centuries, the differences and transformations (functions, social level, dependency status, etc) in the functions and role of castles in different territories (Lithuania propria, Žemaitija, Ruthenian lands), depending on the time and the socio-political circumstances, become clear.

The spatial frames of the work cover the entire territory of the GDL during the discussed period, raising as the main purpose the attempt to make clearer the state's structural and social heterogeneity, on the basis of the castle as an example of the phenomenon. Such parts of the state as Lithuania propria, Žemaitija and the Ruthenian territories are identified. The essential question is legitimate for the structures of the castles of these lands individually, but also looking at them as integral parts of the state. 


\section{The concept of the castle in historiography}

The first works devoted to castles of the GDL appeared as early as the middle of the 19th century ${ }^{4}$. At the beginning of the 20th century, the romantic historiographical tradition of the previous age was continued, even though there were also qualitatively new approaches, aimed not at historical essays and reviews of individual castles, but trying to discuss the economic characteristics of the castle, or to mark the development of castles in a distinct region ${ }^{5}$. The new phase of the research tradition is associated with H. Łowmiański. It is important to note that this historian was the first to talk about the structures of castles, more precisely, of fortified settlements, prescribing castrum, burg with its proprietary suburbium, preurbium, vorburg, hachelwerc etc ${ }^{6}$. At the same time Łowmiański providing the names of the first half of the 13th and 14th century defence fortifications, consistently used the Polish word gród, by which the qualitative difference from the zamek is stressed, expressing both the complicated architectonics of the structure and the social aspect of the phenomenon. Nevertheless, this work started by Łowmiański remained undeveloped, because Lithuanian historiography was 'busy' with the fortification of its own national defence bastion contention, while the Soviet period 'made its own adjustments' in the development of GDL historiography.

${ }^{4}$ M. Baliński, 'Krewo. Starodawny zamek w Litwie', Pisma historyczne, 4 (Warsaw, 1843), pp. 165-180; A. Perlshtein, Opisanie goroda Ostroga (Moscow, 1847); K. Tyszkiewicz, Wiadomość historyczna o zamkach, horodyszczach i okopiskach starożytnych na Litwie i Rusi litewskiej (Vilnius, 1859); J. Bartoszewicz, Zamek Bialski (Lwów, 1881); T. Stecki, 'Radziwiłłowska Ołyka', Przegląd powszechny, 14-15 (Kraków, 1887); A. Perlshtein, Opisanie goroda Ostroga (Moscow, 1847); J. Bartoszewicz, Zamek Bialski (Lwów, 1881); A. Prusiewicz, Zamki i fortece na Wotyniu (1922); B. Brezhgo, Zamki Vitsebshshchyny (Vilnius, 1933).

${ }^{5} \mathrm{M}$. Grushevskii, Iuzhnorusskie gospodarskie zamki v' polovine XVI veka: istoriko-statisticheskii ocherk' (Kiev, 1890). The latter work relies exclusively on materials from the revisions of the castles of the "Ukrainian" lands carried out only in the middle of the 16th century. A work of a different nature devoted to the economy of the castle and its maintenance: A. Grushevskii, 'Povinost' gorodovoi raboty v' Velikom' Kniazhestve Litovskom', Zhurnal' Ministerstva narodnago prosveshcheniia, ch. LIV, № 11-12 (1914), pp. 19-39; idem., Goroda Velikavo Kniazhectva Litovskogo v' XIV-XVI vv. (Kiev, 1918).

${ }^{6}$ H. Łowmiański, Studja nad poczatkami spoleczeństwa i państwa litewskiego, T. II (Vilnius, 1932), pp. 206-224; idem, Studia nad dziejami Wielkiego Księstwa Litewskiego (Poznań, 1983), pp. 327-341. 
A new wave of research into castles in Lithuania dates from the last decades of the 20th century ${ }^{7}$. This tradition determined that a special publication devoted to castles and their cultural heritage appeared ${ }^{8}$. The most important and newly investigated castles also attained individual publications ${ }^{9}$. Among the archaeologists, the works of G. Zabiela and A. Kuncevičius stand out. The first focused his main attention on researching Lithuania's wooden castles, their spread in the current territory of Lithuania, their nature, and the development of their features ${ }^{10}$. In his study, Zabiela also expounded a theory about the progressive disappearance of wooden castles in the 14th century. However, this process may be described more accurately as the transformation occurring at that time of the wooden castle into estates, i.e. in the direction of a change of function, with the castle turning into an economic and administrative unit. And the very transformation/degradation process of castles is related not only to the

7 A. Baliulis, A. Mikulionis, A. Miškinis, Traku miestas ir pilys (Vilnius, 1991); V. Almonaitis and J. Nutautaite, who, relying on the books of the Teutonic Order treasury, discussed the Dubysa castle of the Order and its everyday life, published an article of a quite different nature, see V. Almonaitis, J. Nutautaite, 'Kasdieninis gyvenimas Vokiečiu ordino Dubysos pilyje', Istorija. Lietuvos aukštuju mokyklu mokslo darbai, 57 (2003), pp. 17-25; about the castles and defensive fortifications of the Medininkai land see: R. Batūra, 'XIV a. Medininkų žemès - Žemaitijos centro gynyba: Laukuvos ir Kaltinènų priedanga', Istorija. Lietuvos aukštujų mokyklu mokslo darbai, 59-60 (2004), pp. 17-19. Archeologists: J. Poškiene, 'Senujų Trakų pilies, senovès gyvenvietès ir vienuolyno buitinè keramika (XIV-XVII a. pirmoji pusè)', Lietuvos istorijos metraštis, 1998 metai. (1999), pp. 5-23; G. Zabiela, 'Nuo medinès prie mūrinès pilies (Motai Europoje ir Lietuvoje)', Lietuvos piliu archeologija (Klaipėda, 2001), pp. 11-41; B. Lisauskaitè, 'Trakų archeologiniai tyrimai 1971-1998 metais', Lietuvos piliu archeologija (Klaipèda, 2001), pp. 105-125; A. Kuncevičius, 'Senieji Trakai', Lietuvos piliu archeologija (Klaipèda, 2001), pp. 128-146; individual articles about the castles of the Baltic region see Castella Maris Baltici, 6 (2004).

${ }^{8}$ Lietuvos pilys, 1-5. See specfic articles: O. Trusov, 'Lydos pilis Lietuvos didžiojo kunigaikščio Aleksandro laikais', Lietuvos pilys, 2 (2006), pp. 76-82; V. Jankauskas, 'Pilis ir prestižas: Gediminaičių kunigaikštystès XV a.', Lietuvos pilys, 3 (2007), pp. 66-77; R. Ragauskienè, 'Nuo valdos iki kunigaikštystès: Radvilų Dubingiai (XVI a.-XVII a. pradžia)', Lietuvos pilys, 3 (2007), pp. 77-93.

9 Vilniaus Žemutinès pilies rūmai, 1-5 (1989-2003); Vilniaus Žemutiné pilis XIV-XIX a. pradžioje: 2002-2004 m. istoriniu šaltiniu paieškos, comp. by R. Ragauskienè (Vilnius, 2006); Vilniaus Žemutine pilis XIV a.-XIX a. pradžioje. 2005-2006 m. tyrimai, comp. by L. Glemža (Vilnius, 2007); A. Kuncevičius, R. Jankauskas, R. Laužikas, D. Stankevičiūtè, I. Rutkauskaitè, Radvilu tèvonija Dubingiuose (Vilnius, 2009).

${ }^{10}$ G. Zabiela, Lietuvos medinès pilys (Vilnius, 1994), pp. 180-181. 
end of the attacks on Lithuanian territory by the Teutonic Order but also to the internal changes in the state of Lithuania: the conversion of military-defence objects into economic-administrative centres was the consequence of political and social changes in the early GDL ${ }^{11}$. In an article about the wooden castles of Eastern Lithuania, Zabiela stresses the role of the increasing momentum of the colonisation of the Slavs in the ninth and tenth centuries, and the conflicts arising as a result. This, in Zabiela's opinion, had a decisive importance on the appearance of castles in the contact zone between the Balts and the Slavs ${ }^{12}$. This article perhaps does not cast doubts on the very naming of the process, but more on the question of the very concept of the castle. In the text, words such as pilis/pilaitélitvirtinta gyvenviete (castle/castle/fortified settlement) are used rather vaguely and freely. On the other hand, the rudiments of the castles should also be associated with the changing social relations, and not only with the external threat. In one way or another, this article touches on the especially important space of pre-state Lithuania propria, and tries to explain the development of the emergence and formation of regional differences.

Kuncevičius, in his own synthesis Lietuvos viduramžiu archeologija $^{13}$ [Lithuanian Medieval Archaeology], raises the idea about the nature of the construction of stone castles as residences of the rulers at the juncture of the 14th and 15th centuries, and thus the qualitative changes in the development of building castles and the formation of residences. Here, most of all, the archaeologist has in mind the ring of castles situated in the territory of Lithuania in the narrow sense. However, in response to the latter idea, it should be emphasised that we have clearer data only about the construction of Trakai island castle as an undoubted residence at the beginning of the 15th century ${ }^{14}$. Meanwhile, the Upper Castle in Vilnius acquired new forms only after a fire in 1419. Nevertheless, despite the lack of historical records for a more precise identification of the process, this does not hinder us in talking about the residential role of individual castles (Vilnius, Trakai, Kernavè) already in the 14th

${ }^{11}$ R. Petrauskas, 'Ankstyvosios valstybinès struktūros Lietuvoje XIII amžiuje-XV amžiaus pradžioje', Lietuvos istorijos studijos, 16 (2005), pp. 19-30.

${ }^{12}$ G. Zabiela, 'Pilys Rytų Lietuvoje valstybès kūrimosi metu', Lietuvos valstybè XII-XVIII a. (Vilnius, 1997), pp. 459-472.

${ }^{13}$ A. Kuncevičius, Lietuvos viduramžiu archeologija (Vilnius, 2005), pp. 51, 58.

${ }^{14}$ Z. Ivinskis, 'Trakų Galvès ežero salos pilis', Vytauto Didžiojo kultūros muziejaus metraštis, 1 (Kaunas, 1941), pp. 135-198. 
century, which eloquently complement the creation of the institutional estate and central offices launched by Vytautas.

E. Gudavičius, even though he did not study specifically the question of Lithuania's castles, speaking about features of the organisation of the draft army, made clear the importance of castles in the creation of the management system, and formulated a theoretical model of the GDL castle in the late 13th and 14th centuries and the districts belonging to them ${ }^{15}$, on the basis of which the land administration system, the defence system and the network of interdependent communication were formed. It is worth mentioning here by its conception the conspicuous article of A. Nikžentaitis on the defensive system of the Nemunas and Jüra river castles ${ }^{16}$, and also the later study ${ }^{17}$, which briefly discusses the military organisation along the Nemunas and the defence system in Žemaitija, in the historian's expressed formula: castle - parish - land - state. The works of Gudavičius and Nikžentaitis, while supplementing each other, stress the concept of the functioning of an integral system of castles and their territories being formed.

T. Baranauskas has devoted two articles to Lithuanian castles. The first ${ }^{18}$, dealing with wooden castles in the late 13 th and 14th centuries and their localisation, critically evaluates the conclusions of earlier historiography. At the same time, based on the chronicles of the Teutonic Order, it discusses the possible appearance of castles and castle design features. The second article attempts to find links between the castle and the church in general, and sacral areas and state-territorial structures at certain intersection points. In addition, the article attempts to formulate a difference between the stone castles' regions (Kęstutis - Trakai; Algirdas - Krèva, Lyda, Vitebsk; Liubartas - Volhynia; Karijotaičiai - Podolia), and the chronology characterising them. Meanwhile, with the rule of Vytautas,

15 E. Gudavičius, 'Lietuvos pašauktinès kariuomenès organizacijos bruožai', Karo archyvas, 13 (1992), pp. 52-53; idem, 'Lietuvos valstybès struktūra Gedimino laikais', Lietuvos europejimo keliais: istorinès studijos, comp. by A. Bumblauskas, R. Petrauskas (Vilnius, 2001), p. 139.

16 A. Nikžentaitis, 'Rašytiniai šaltiniai apie lietuvių pilių gynybinę sistemą XIII a. pabaigoje-XIV a. pradžioje', Lietuvos TSR mokslu akademijos darbai, Serija A. 3 (96) (1986), pp. 51-63.

${ }^{17}$ Idem, Nuo Daumanto iki Gedimino. Ikikrikščioniškos Lietuvos visuomenès bruožai (Klaipėda, 1996), pp. 55-69.

18 T. Baranauskas, 'Lietuvos medinès pilys rašytinių šaltinių duomenimis', Lietuvos archeologija, 24 (2003), pp. 57-105. 
the transformation of wood into stone in the GDL is completed ${ }^{19}$. Although the author bases his own conclusions on the abundant archaeological literature, one should assess carefully the assumption that there was a purposeful and consistent process (programme) for 'turning into stone' castles ${ }^{20}$.

In GDL historiography, castles have been treated frequently as a matter of course, not requiring clearer chronological and problematic definitions of the phenomenon. Two issues are important here. What are the concepts and definitions of the castle that appear in GDL historiography? What can be helpful, and what possible alternatives of interpretation does foreign historiography offer, both from Central and Eastern Europe (especially Poland, the Teutonic Order) and Western Europe?

In GDL historiography, a few concepts of the castle dominate, frequently dependent on the spectrum of the particular interests of the specific specialist. Without trying to examine in chronological order the positions of individual authors, these definitions of the castle stand out. Zabiela, speaking about the wooden castles of the 11 th to 14 th centuries, perceives the castle as a defensive installation of a closed-type fortification (a defensive part of the complex) with a forework, lower ward, base court, outer bailey and a base settlement ${ }^{21}$. In this case, a comment on the dating of castles is necessary. In particular, an archaeologist should be more cautious in postponing the beginning of Lithuanian castles to the 11th century, because at a similar time in Western Europe, the castle had just become an integral part of the local landscape. The question is, whether these defences can be linked directly to the place that existed, or implicitly existed in a castle? And what is generally called a castle and what is not? In this case, it is essential to resolve the question of the very typology of pilis/pilaite/itvirtinta gyvenviete, the criteria (socio-political, architectural, etc) and chronological boundaries of the latter formulation.

19 Idem, 'Zamki i kościoły litewskie XIV-XV wieku jako ośrodki kultury', Środowiska kulturotwórcze i kontakty kulturalne Wielkiego Księstwa Litewskiego od XV do XIX wieku (Warsaw, 2009), pp. 11-23.

20 Similar considerations can be detected also in Polish historiography; see Z. Kaczmarczyk, 'Organizacja obrony kraju w czasach Kazimierza Wielkiego', Studia Historyczne ku czci Stanistawa Kutrzeby, T. II (Kraków, 1938), pp. 330, 333-334; idem, Monarchia Kazimierza Wielkiego, T. I-II (Poznań, 1939-1946); idem., Kazimierz Wielki (1333-1370) (Warsaw, 1948).

${ }^{21}$ Zabiela, Lietuvos medinès pilys, p. 57. 
Kuncevičius, in his already-mentioned study, explains the medieval castle very similarly, as a closed, defensive and residential complex $^{22}$. Meanwhile, Gudavičius and Nikžentatis perceive the castle as a specific territory with certain social categories, and the castle residents as having the features of a exclusive social group ${ }^{23}$. With this approach, we can already grasp the wider social nature of the castle and its dependent territories (districts), as well as its developed structure.

The Belarusian historian M. Tkachev in his studies touched on the architectural side of GDL castles, distinguishing the so-called keep type in French (donjon) castles $^{24}$ : Krèva, Lyda, Medininkai could be regarded as such. However, the key feature of the work by this researcher is that there was an attempt to distinguish the castles of the sovereign (state) and the castles of the nobility, in such a way including the social dimension in the concept of the castle, but, unfortunately, without trying methodologically to mark the chronological and typological differences between the castles of the nobility, and the conditions of their emergence or later in the second half of the 16th century of bastion castles, palaces (Biržai, Nesvyžius etc).

It is also worth mentioning one of the most recent attempts to present the concept of the castle which the Belarusian historian G. Semianchuk outlined. The historian appoints the following evaluation criteria for the castle: architectural, archaeological and historical-sociological ${ }^{25}$. What is important is the fact that the castle's appearance is associated with the qualitatively changed social conditions: feudal relations, large land ownership, and the gradual acquisition of latter immunity. Thus, in the definition of the genesis of the castle, the social aspect, which is understood as a necessary condition for the castle, occupies a very important place; the castle in this study is already perceived from the point of of social history.

${ }^{22}$ Kuncevičius, Lietuvos viduramžiu archeologija, p. 39.

${ }^{23}$ See footnotes $15-17$.

${ }^{24}$ One can add that the latter can be held as such only in part, see M. Tkachev, Zamki Belorussii (Minsk, 1987); idem, Zamki i liudzi (Minsk, 1991).

${ }^{25}$ G. Semianchuk, 'Dereviannye zamki Belarusi XIV-XVII vekov (sostoianie izuchennosti i issledovatel'skie problemy)', Lietuvos pilys, 4 (2008), pp. 18-19. Also the earlier article, see idem, 'Wschodnioeuropejski zamek we wczesnym średniowieczu - geneza i funkcjonowanie (według danych Białorusi)', Zamki $i$ przestrzeń społeczna w Europie środkowej i wschodniej (Warsaw, 2002), pp. 133-145. 
Another characteristic feature of the historiography is the restriction of research according to the borders of contemporary countries. In this an actual historical phenomenon and its development process is artificially split, and this poses a number of methodological problems in the attempt to identify consistently and systematically the characteristics of the evolution of the phenomenon.

There is a different tradition in the study of the phenomenon of the castle in foreign historiography. In the works of Polish authors, one immediately notices the clear boundary between the complex to translate into the Lithuanian language gród (a settlement surrounded by fortified walls; German Burgwall, English gord, Czech hradiště, Russian городище) ${ }^{26}$ and zamek (German Burg, Englsih castle, Czech hrad, Russian замок). This differentiation is based on the typology of the defence object, and with that directly related criteria of chronology. The castrum encountered in the Chronicle of Gallus Anonymus (11th-12th century) in Polish historiography is interpreted not as a castle, but as a kind of defensive walls and object restricted by other fortifications: gród. Chronologically, gród ${ }^{27}$ dates back to the tenth to 13th centuries, and is understood as a certain phase in the development of defensive fortifications towards the formation of the castle.

The problem of historical concepts and their relation to the terminology of the sources has been discussed for a long time in historiography. On this question, the articles about the phenomenon of the castle in the Dictionary of the Middle Ages by several authors from different countries (F. Schwind, F. Graus, E. Fügedi, M. Hellmann, A. Poppe, K. Rüss, G. Binding, H. Ebner, H.P. Baum et al.)

${ }^{26} \mathrm{~K}$. Długosz-Kurczabowa, Wielki stownik etymologiczno-historyczny języka polskiego (Warsaw, 2008), pp. 225-226; in the dictionary a very broad amplitude of the translation of gród is given: 1. hill, castle, fortress, 2. city, capital, residence. However, the examples of the provided languages definitely speak about the global prevalence of this phenomenon and the links of the concept with fencing, home, garden; hence events that have clear spatially defined boundaries.

${ }^{27}$ The historiography of this problem is abundant; see B. Miśkiewicz, Studia nad obrona polskiej granicy zachodniej w okresie wczesnofeudalnym (Poznań, 1961), pp. 52-79; A. Swieżawski, Przemyst król polski (Warsaw, 2006), pp. 212-213; J. Rozpędowski, 'Początki zamków w Polsce w świetle badań warowni legnickiej', Kwartalnik architektury $i$ urbanistyki, t. X, z. 3-4 (1965), pp. 149-179; idem, 'Ze studiów nad palatiami w Polsce', Biuletyn historii sztuki, R. XXIV, Nr. 3/4 (1962), pp. 243-255; K. Modzelewski, 'Organizacja grodowa u progu epoki lokacji', Kwartalnik historii kultury materialnej, R. XXVIII, Nr. 3 (1980), pp. 329-340; K. Olejnik, Grody i zamki w Wielkopolsce (Poznań, 1993), pp. 7, 51-52, 172-173, 175. 
are considered to be exemplary historiographical work ${ }^{28}$. In them, systematically, beginning with the typology of castles, and ending with the characteristics of individual regions, the castle terminology (naming) and its changes in different sources, the main features of the castle and the peculiarities of its development in different countries, are marked out. In Western Europe (and undeniably in the territory of the Teutonic Order, though the emergence of the castle and the circumstances of its formation here were different, bearing in mind the organisation and the social structure of this state) ${ }^{29}$, the reasonably raised questions about the differentiation of the phenomenon of the castle, about the characteristics of the terminology of sources, it is stated that the form, function and relationship of castles varied very much, and also their designations varied in the sources. This is due to the fact that typologically the castle in Western Europe was a very heterogeneous phenomenon in both its functions and architectural solutions, as well as its social nature. The latter idea is certainly supported by the numerous historical terms (terminus technicus) formulated in German historiography, expressing the complexity of the existent social reality and the material civilisation, and thus the castle conforms to the local situation. For example, according to the castle construction site, the typology differs: castles built on naturally formed mountains or hills, German Höhenburg; a castle surrounded by water or fortifications surrounded by water, German Wasserburg; a castle or defence tower built on so-called motes, German Turmhügelburg, a community castle or hiding place, German Volks- und Fluchtburg; typology according to social character: the early middle ages manor-castle, after completing the 'control the way' functions, German Pfalz and Reichsburg; the castle of a duke, German Fürstenburg, the castle of a count, German Grafenburg; a nobility (knights), ministerial or 'serviceman' castle, German Hochadel-Ministerialen- or Dienstmannenburg; a town or church castle, German Stadtburg, Kirchenburg et al.) ${ }^{30}$.

${ }^{28}$ Lexikon des Mittelalters, Bd. II (Munich-Zürich, 1983), pp. 958-1003; also about the castle as a certain government, judicial, economic etc. structure see H.-K. Schulze, Grundstrukturen der Verfassung im Mittelalter, Bd. 2 (Stuttgart, 2000), pp. 86-124.

${ }^{29}$ T. Torbus, Die Konventsburgen im Deutschordensland Preußen (Munich, 1998).

${ }^{30}$ Lexikon des Mittelalters, p. 958. 
This experience of historiography forces one to take a fresh look at the tradition of research into GDL castles. The comparative aspect can help prevent anachronistic assessments and discover new approaches to a historical event. Once again, it becomes clear that it is impossible to know the phenomenon of the castle adequately, without looking at its wider social environment. Therefore, it is necessary to understand and interpret it both as a specific space, and as a social structure. However, the assumption of these studies is a clearer notion of the castle.

\section{The concept of the castle}

It is important to state the fact that, in general, there exists a bright semantic uncertainty about the word, term and concept. Concept is a word, but not every word is a concept. The introductory article by Reinhard Koselleck to the monumental dictionary Fundamental Concepts of History aptly reveals the semantic dynamics of historical concepts $^{31}$. One can talk about a concept only when the meanings of an individual term, expressing the order of things (Sachverhalt), are bundled and discussed in connection with the function of a definition. Meanwhile, the term accommodates in itself features of the existing order of things; its meaning can be substantive (specific), although defined differently ${ }^{32}$. Speaking simply, a term has a relatively specific definition. Content-wise, the term is not as capacious as a concept, but its shape is more completed, more substantiated, less conditional and contradictory. Thus, talking about the lexicon of sources, the word for the castle is understood as the simultaneous linguistic expression of a particular object; meanwhile, the content which he gives in the text as a historical term (terminus technicus) is formulated as the basis for the interpretation of the source.

An analysis of the terminology of sources raises several fundamental questions. First, how specifically is the castle referred to

${ }^{31}$ Geschichtliche Grundbegriffe. Historisches Lexikon zur politisch-sozialen Sprache in Deutschland (Geschichtliche Grundbegriffe), ed. O. Brunner, W. Conze, R. Koselleck, Bd. 1 (Klett-Cotta, 1992) pp. XIII-XXVII. Attention should be drawn to the article of E. Banionis that appeared in 1988 about the problems of naming the books of Lietuvos Metrika [Lithuanian Metrica]. The highlighting of the latter problem could serve as a starting point resolving similar questions related to historical terminology, and also to concepts. See E. Banionis, 'Lietuvos Metrikos knygos: sąvoka, terminas, definicija’, Lietuvos istorijos metraštis, 1988 metai (1989), pp. 135-148.

${ }^{32}$ Geschichtliche Grundbegriffe, p. XXIII. 
in contemporaneous historical sources? Second, what lies beneath the literal, but often fragmentary information? Third, how did the concept of the castle change over time; and finally not so much the very concept, as the information of the sources about it reaching us?

In the first Lithuanian dictionary, Dictionarium trium linguarum by K. Sirvydas, which appeared about 1620, pilis (castle) is described as a building and defensive object, but is appropriately named as zamek, munio (?), pilis ${ }^{33}$. In the 17th-century Clavis GermanicoLithvania $^{34}$ and in the later 18th-century ${ }^{35}$ Lithuanian-German, German-Lithuanian dictionaries, a translation of pilis is provided, for example Pillis - Die Burg, die Festung, Schloß, although the latter $(S c h l o \beta)$ is understood today as rümai (palace) and is related to the Renaissance, and in many cases with different functions of this structure and architectonics. Together in the dictionary a rather unusual translation option is proposed: Burg, Schlo $\beta-P i l-$ lis, Atsigintuve, Ißgelbetojis, also Festung - Festingè, Szancas (?), Pillis. One might think that the word pilis is of ancient origin. This is confirmed by the appearance (the first mention dates back to the beginning of the 16th century) of the related word piliakalnis (mound) in written sources ${ }^{36}$.

Talking about the multilingualism of GDL sources, we encounter one major problem - the lack of clarity of the semantic content of a phenomenon named in different languages, i.e. trying to give a common name to phenomena of different regions of civilisation, or simply linguistic traditions, and thus to the words for them. In

${ }^{33}$ Pirmasis lietuvių kalbos žodynas: Konstantinas Širvydas. Dictionarium trium linguarum (Vilnius, 1979), pp. 8 (106), 24 (122), 64 (162), 270 (368), 552 (660); [...] żotnierz osadzony na zamku. Praesidiarius miles. Karieywis piliy pastatitas [...].

${ }^{34}$ Clavis Germanico-Lithvana. Rankraštinis XVII amžiaus vokiečiu-lietuviu kalbu žodynas = Handschriftliches deutsch-litauisches Wörterbuch des 17. Jahrhunderts, ed. A. Ivaškevičius, J. Marcinkevičius et al., I dalis (Vilnius, 1995), p. 412 (415).

${ }^{35}$ Vocabvlarivm Litthvanico-Germanicvm, et Germanico-Litthvanicvm... (Halle, 1730), pp. 98, 165; Litauisch-Deutsches und Deutsch-Litauisches Lexicon (Königsberg, 1747), pp. 88, 107, 138, 312; J. Brodovskis, Lexicon Germanico-Lithvanicvm et Lithvanico-Germanicvm, T. III: Žodžiu indeksas, ed. V. Drotvinas, (Vilnius, 2009), pp. 79, 114, 115, 190, 303, 309, 466, 554, 810, 888. Also see Pirmoji lietuviu kalbos gramatika 1653 metai (Vilnius, 1957), pp. 64 (160), 161 (257), 168 (264): Excipe Pillis arx $[. .] ;.[.$.$] qvae Faeminina sunt [. .] ;.[. .$.$] atejau ing pilli veni in$ arcem $[\ldots] ;[\ldots]$ uz pillies ultra arcem $[\ldots]$.

${ }^{36}$ K. Jablonskis, Lietuviški žodžiai senosios Lietuvos raštinių kalboje, I dalis: Tekstai (Kaunas, 1941), p. 167: Продал есми свою дђлнииу земли на пол бочки [...] а тая земля лежит подле великое дороги у пиликолни [...]. 
this context, it is necessary to draw attention to the laconic nature of the greater part of the sources, and the ambiguity of the words chosen to name phenomena. One very typical example, the siege of the Apuoles pilis [Castle of Apuole] is offered. Although this source describes times that go well beyond the chronological frames of this article, nevertheless, its terminology and the dictionary of its later translation reflect well the problems dicussed here. In the source, describing the Viking attack in 853, three different words: urbs, civitas and castrum ${ }^{37}$, are used to name one and the same object. In chronological order, this entire event can be divided into several episodes: a) reaching another fortified settlement of the Courlanders called Apuole (ad aliam urbem ipsorum, quae Apulia dicebatur); (b) there were 15,000 troops in this fortified settlement (Erant autem in ea urbe quindecim milia hominum bellatorum); c) barricading in the fortified settlement and its defence (conclusis ipsis in civitate isti a foris urbem debellare) [my translation]. In this case, a problem arises due to the source of the translation and its interpretation. It is fitting to make a brief stop at the translation of the source, published in the first volume of Lietuvos istorijos šaltiniu [Lithuanian Historical Sources] ${ }^{38}$. In particular, attention is drawn to the fact that different words are relatively freely translated, thus distorting the local realities of the period. It is obvious that a unified translation of different words naming the same object is justifiable, but understanding the mentioned Latin words as pilis exceeds the situation of this region's material and social order at that time. Even bearing in mind the relatively high level of material civilisation in the region compared with Southeastern Lithuania, there cannot be sufficient qualification for the statement that in Curonian territory at that time there could have stood a castle, rather than a fortified settlement.

The pilys [castles] of the nobles of the east Baltic tribes are mentioned more often in sources at the beginning of the 13th cen-

${ }^{37}$ Vita Anskarii auctore Rimberto. Accedit Vita Rimberti, ed. G. Waitz (Scriptores rerum Germanicarum) (Hanover, 1884), pp. 60-62.

${ }^{38}$ Lietuvos istorijos šaltiniai, Feodalinis laikotarpis, T. I (Vilnius, 1955), p. 21: prie kitos ju pilies, vadinamos Apulia. O toje pilyje buvo 15000 kovotoju [...] (gyventojai) užsidarè pilyje; vieni iš lauko pradejo pili pulti, antrieji iš vidaus drąsiai priešintis [...]. Lietuvos istorija. T. II: Geležies amžius, ed. G. Zabiela et. al. (Vilnius, 2007), p. 315. In the latter synthesis quite freely not trying to maintain consistency such words as pilis and pilaite are used speaking about fortified pre-state Baltic settlements, see pp. 202-207. 
tury. The classification and definition of these fortifications is very difficult in this case, because contemporary sources do not supply more accurate data about these objects. Therefore, one should use the concept of pilis very carefully with regard to defensive objects from this period. An example could be the pilys mentioned in the Chronicle of Henry of Livonia from the 13th century. However, the legitimate question arises: what is called a castle, and what are fortified defenses or just a hiding place? In briefly attempting to define the main problem, one should note several places mentioned existing in the chronicle in which the pilys of the Baltic tribes are mentioned. For example, in 1185, the Chronicle mentions that the Lyvians had no fortresses (quod municiones nullas habeant), and promises that after the Žiemgaliai (Semigallians) are baptised a castle (castra fieri pollicetur) ${ }^{39}$ will be built. Meanwhile, already in 1205 , it describes the episode of the negotiations between the Livonian Order and the Žiemgala (Semigallia) chief Viestarts, in which the main condition specified is that each Žiemgala castle (si de quolibet castro Semigallie $)^{40}$ must give up one hostage. All of this provides the opportunity to conduct a parallel between the different Baltic tribes at the time of the emergence of castles in the territories of these societies and more or less similar conditions. There is no doubt that the defence fortifications already existed in the lands when the Order arrived. However, historical sources and archaeological studies do not allow one to fully understand their typology. However, if we define and realise the castle as an integral part of the social reality, which is characterised by the formation of state-like organisations with a well-developed control system (e.g. taxes, payment by working-collective assistance, tributes), crystallising the clear internal social differentiation, and finally a complex structural mechanism, then in the territory inhabited by the Baltic tribes, at least in the first half of the 13th century, there were no castles. The material, social and organisational potential of the tribal

${ }^{39}$ Scriptores rerum Germanicarum, vol. 31: Heinrici Chronicon Livoniae, ed. L. Arbusow, A. Bauer (Hanover, 1955), p. 3. Attention is drawn to the term municio used in the source and its multiple meanings (e.g. fortification, fortress, wall, building).

${ }^{40}$ Ibid., pp. 48, 50. Also about the mentioned Semigallian castle see p. 100: ad castrum Selonum [...]. 
society was too poorly developed for it to have been possible to build more complex structures and buildings for diverse functions. Therefore, the castrum mentioned in the sources at the beginning of the 13th century would be more appropriately called fortified settlements (similar to the Polish gród, German Burgwall, Czech hradiště), which are typical for the eras of tribal society and the early monarchy.

Here, we should return to the situation in Western Europe, where the first castles are dated to about the ninth and tenth centuries, while earlier fortifications, such as the residences of rulers, are identified as Pfalz, palatium (not classifying the latter as medieval castles) $)^{41}$. In such a case, GDL historiography also needs a certain typologisation and an adapted terminology.

Reviewing the designations of castles found in 14th and 15thcentury GDL sources, attention should be drawn to a few more specific words in the Latin tradition: arx, castellum, fortalitium. In the dictionary they do not have an unambiguous connotation ${ }^{42}$, but this more likely implies the unstable and sporadic practice of their use in different contexts, rather than the attempt to identify more accurately a specific object ${ }^{43}$.

${ }^{41}$ For more information see R. McKitterick, Charlemagne. The Formation of a European Identity (Cambridge, 2008), pp. 170-171; the author describes the formation of the residences of Charlemagne, their geography and functions. Also see Einhardas, Karolio Didžiojo gyvenimas, tr. M. Čiurinskas, introduction and explanations by R. Petrauskas (Vilnius, 2005). Attention is directed in the original text to the Latin naming of Charlemagne's residences: [...] palatia operis egregii $[\ldots]$, p. $70,[\ldots]$ comes palatii $[\ldots]$, p. 86 . The similarities can be met in the tenth century in the times of Otto the Great when the talk is not in any way about castles, but just about certain residences (Palast), see E. Lehmann, 'Der Palast Ottos des Grossen in Magdeburg', Architektur des Mittelalters. Funktion und Gestalt (Weimar, 1984), pp. 42-62.

${ }^{42}$ For a presented multifaceted translation see Stownik taciny średniowiecznej $w$ Polsce, T. I, II, IV, (Wrocław-Kraków-Warsaw-Gdańsk, 1953-1977).

${ }^{43}$ To illustrate this statement, one can rely on analogies; e.g. the examples of two German space castles clearly testify to this, when the subject is named ever differently in the course of several decades. The cases of two Hammerstein and Nuremberg castles, the designations of which in the sources ranged from castrum, castellum, arx, munites, urbs, borch to burgus are presented. One should bear in mind that, according to the researcher of these castles, no larger changes during the discussed period occurred in the structure of the castles while in the meantime the designation changed; see A. Thon, 'Studien zu Relevanz und Gültigkeit des Begriffes „Pfalz" für die Erforschung von Profanbauwerken des 12. und 13. Jahrhunderts', Forschungen zu Burgen und Schlössern, 7 (2002), pp. 45-72. 
One has to speak about a different situation when meeting the tradition of Ruthenian (Cyrilic) writing and the territory of the former Kievan Rus'. In Ruthenian writing, a variation of an encountered word in the sources, град, городъ, городокъ, hrad, horod ${ }^{44}$, later appeared in the language of the office of the Grand Duchy. Only at the turn of the 15 th and 16th centuries was this term replaced in the language with the Polonism замокъ, замочокъ, zamok ${ }^{45}$. It is important to emphasise the following sources of terms like городb and градz, which do not have the same meaning ${ }^{46}$. The sources do not reveal exactly when the talk is about a city, and when about a castle. Looking from the other side, the city is understood as a broader-content object than the castle, while for any city one of the necessary conditions was the latter. Nevertheless, it is very likely that the mention of a city should often be understood as a castle, because the latter in Europe in the Middle Ages was one of the basic features of the landscape touched by man (bearing in mind the connection between the beginning of the castle and the city, and from that the importance of the castle as the potential core of the city) ${ }^{47}$. The very meaning combination of the words городъ and градъ implies two phenomena: the genetic ties and the common features in the development of the city and the castle. From a linguistic perspective, one must remember that the Indo-European Lithuanian gardas / Czech hrad / Polish gród / Danish gaard / Old Norwegian gardr primarily meant a walled, i.e. 'site-specific' space, farmstead, yard,

${ }^{44}$ Novogorodsckaia pervaia letopis' starshego i mladshego izvodov (Moscow-Leningrad, 1950), pp. 475-476; J. Jakubowski, 'Opis Księstwa Trockiego z r. 1387', Przeglad historyczny, 5 (1907), pp. 22-47; Latopisiec Litwy i kronika ruska (Vilnius, 1827), pp. 50-53, 56-57.

${ }^{45}$ Lietuvos Metrika, Užrašymu knyga 25 (1387-1546), ed. D. Antanavičius, A. Baliulis (Vilnius, 1998), p. 102, (1501); p. 92, (1504 m.). Meanwhile, in a document written in 1480 a castle was designated still by an 'old' Ruthenian noun: маю тот город Лучоскъ держати [...]; Lietuvos Metrika, Užrašymu knyga 4 (1479-1491), ed. L. Anužytė (Vilnius, 2004), pp. 107-108.

${ }^{46}$ Materialy dlia slovaria drevne-russkago iazyka po pis 'menym ' pamiatnikam', T. I (St Petersburg, 1893), pp. 555-556; for gorod' presented variations of translation: 1. barrier, wall, 2. fortifications, fortress, city, 3. stone walls, pp. 575-576; grad' translation: 1. wall, barrier; 2. garden; 3. city.

${ }^{47}$ E. Gudavičius, Miestu atsiradimas Lietuvoje (Vilnius, 1991). 
as a certain centre of the world ${ }^{48}$. Therefore, in Russian sources (tenth to 13th-century annals), first of all one has in mind namely a fenced area, a fortified settlement, from which developed the more complex structure, the city. At the same time, trying in detail to make clear the problematic areas of the Ruthenian castle space, one has to keep in mind two mentioned spatial elements of the castle: детинеи and посад. The first of these is perceived as an internal part of the castle, limited by the castle's walls, and the second as a forecastle (suburbium, preurbium, vorburge), a settlement, on the external walls of the defence fortifications ${ }^{49}$. Nevertheless, in general, the castles of the Ruthenian part of the GDL had a somewhat different development trajectory, because the state structures of Kievan Rus' still survived there. On the other hand, a reservation must be made because of how in Russian historiography the question of the city/castle is 'intertwined', not fully distinguishing the features of these two, definitely interrelated, phenomena ${ }^{50}$. To summarise, the principle problem of Russian historiography is considered to be the undifferentiated use of the word город as city, which is a direct and uncritical transfer of the terminology of contemporaneous sources into a modern language.

48 Russisches etymologisches Wörterbuch von M. Vasmer, Bd. 1 (Heidelberg, 1953), p. 297; Etimologicheskii slovnik ukrains 'koi movi, T. I (Kiev, 1982), pp. 70-71, 580. A. Gurevičius describes this picturesquely with examples of Scandinavian space; see A. Gurevičius, Viduramžiu kultūros kategorijos, tr. V. Nekrašienè (Vilnius, 1989), pp. 51-52. By the way, the image of the farmstead and yard as the world axis (axis mundi) is extremely common in mythology, which provides a lot of information about prehistoric times. The Rumanian researcher of history of religions M. Eliade has extremely vividly revealed this; see. M. Eliade, Amžinojo sugrižimo mitas: archetipai ir kartote, tr. P. Račius (Vilnius, 1996); idem, Šventybe ir pasaulietiškumas, tr. P. Račius (Vilnius, 1997).

49 M.N. Tikhomirov, Drevnerusskie goroda (Moscow, 1956), p. 242; Entsiklopedicheskii slovar, T. XXIV (St Petersburg, 1898), p. 656. Moreover, both the interior and exterior structures of the Russian and later Ruthenian GDL castles were more complicated, but there is insufficient space to discuss this problem in more detail. One can only mention such terms of castle structures as gorodnia, ostrog.

${ }^{50}$ P.A. Pappoport, Ocherki po istorii voennogo zodchestva severo-vostochnoi i severo-zapadnoi Rusi $X-X V$ vv. (Moscow-Leningrad, 1961); N.V. Sapazhnikov, 'Oboronitel'nye sooruzheniia Smolenska (do postroiki kreposti 1596-1602 gg.)', Smolensk i Gnezdovo (k istorii drevnerusskogo goroda) (Moscow, 1991), p. 50-78; K. Nosov, Russkie kreposti i osadnaia tekhnika VIII-XVII vv. (Moscow, 2003); Iu.G. Ivanov, Starannye kreposti Rossii (Smolensk, 2004). 
Speaking about written sources in the Middle-High German (Mittelhochdeutsch) dialect, the nouns used huse, hwsze, hawsze, huze, huwsze, husse, hus, hous ${ }^{51}$ as well as burc, burge ${ }^{52}$ are emphasised. One can notice that consistently (both in the Order's Wegebericht and in the correspondence of Vytautas with the Teutonic Order) the first of the indicated nouns (huse) is used, concretising the place name. This consistency, supported by the fact that next to them are used nouns such as koni(n)ges dorff, koni(n)geshoff, together with Andrewshoff, Iwanendorfe, Wissegirdendorffe, eponyms referring to the holdings of specific individuals, and at the same time referred to as the qualitative distinction between objects. Hence, the Wegebericht scouts and compilers accurately described the distinctions between the named objects. Of course, in the sources exceptional cases also occur, such as in several of the same accounts by Teutonic Knight scouts, there is mention of the town of Eišiškès (Eykschischken eyne stadt), although in an earlier note, we find the Eišiškès estate with an abandoned castle (Eyksiskindorffe, eyme wüsten huse) ${ }^{53}$.

It is important that when comparing sources written in different languages, one can note that the terminology throughout the whole discussed 14th to 16th century period maintains a certain consistency. Thus the German huse, hwsze, hawsze, huze or burc, burge correspond to the Russian град, городъ, городокъ, while the latter, due to the influence of the Polish language from the late 14th century to the early 16th century are changed to zamok, замокъ, замочокъ. At the same time, castrum is used as the equivalent of

${ }^{51}$ Codex epistolaris Vitoldi Magni Ducis Lithuaniae 1376-1430 (CEV), ed. A. Prochaska (Cracow, 1882), pp. 51, 54, 775, 709, 450, 555, 319, 184, 256; Scriptores rerum prussicarum, vol. 2: Litauischen Wegeberichte (Litauischen Wegeberichte), (Leipzig, 1863), pp. 662-708. Attention is drawn to the provided translation of hus, which in older dictionaries refer to a dwelling house or a building, according to the German language, characteristic of the components of the second word; see. Bibliothek der gesamten deutschen national Literatur, III. Abteilung, Bd. 1, Mittelhochdeutsches Wörterbuch von A. Ziemann (QuedlinburgLeipzig, 1838), p. 167; the translation of single-storey houses restricted by walls was provided; Mittelhochdeutsches Wörterbuch, comp. W. Müller, Bd. 1 (Leipzig, 1854), pp. 737-741. Mittelhochdeutsches Handwörterbuch, comp. M. Lexer, Bd. 1 (Leipzig, 1872), pp. 1399-1400. In a newer dictionary a few possible options for the meaning of hus were provided: house, residence, castle, manor, see B. Hennig, Kleines Mittelhochdeutsches Wörterbuch (Tübingen, 2001), p. 168.

${ }^{52}$ Livländische Reimchronik, ed. L. Meyer (Paderborn, 1876), pp. 134, 228. See the small dictionary at the end of this publication; especially to the translations of the words hus (1. fortified house, 2. castle) and burc (1. castle, 2. city).

${ }^{53}$ Litauischen Wegeberichte, pp. 700-701. 
those words in Latin texts, with exceptions speaking about the 13th century and earlier times.

The designations of castles in Lithuania, as well as of the other Baltic tribes, appearing in 13th-century sources should not overshadow the fundamental changes that occurred during the period of the formation of the state. The fact that the 13th-century chronicles and annals use the same words as 15 th-century sources does not necessarily imply that we are dealing with the same subject. Historical research is based on the terminology of the sources, but is required to disclose the development of historical phenomena.

\section{The phenomenon of the castle between structures and social history}

The castle as a segment of social reality is often perceived and analysed in historiography separately from the general structure of the state, in this case, the GDL. Such studies limit the possibility to explain the appearance of the castle as a phenomenon and the circumstances of its evolution, the essential breaks in the middle of the very phenomenon. Therefore, the question of the castle should be interpreted and explained in a wider perspective of various phenomena and processes, not failing to introduce into circulation also those which at first glance often appear to have nothing in common (e.g. changes in the self-awareness and self-identification of the nobility, various GDL lands and their social structure, etc).

On the other hand, it is appropriate to evaluate in a differentiated manner the territorial and social heterogeneity of the GDL, which often implies the different nature of these same phenomena and development prospects. Thus, one can take into account territories

such as Lithuania propria, Žemaitija and the Ruthenian lands, which can potentially be divided into even smaller units, and the different castles as conditions for the development of the phenomenon and the processes that occurred in the 14th to the early 16 th centuries. Hence, the assumption can be put for the formerly existing discontinuities of the castle phenomenon in the GDL territory and the effort to highlight them.

The history of structures provides an opportunity to try to formulate a generalisation and giving a type to the interpretative model, not ignoring the distinctive features (individualities). Meanwhile, social history is perceived only as part of the history of structures, focus- 
ing on research into issues of social structures, processes and actions. The key task in this particular case is an attempt to coordinate these approaches with each other, trying to highlight the ever-comprehensive multilayeredness of the investigated phenomenon. The castle and its structure as a phenomenon is an expression of a particular sociopolitical situation, and therefore cannot be interpreted in isolation from the social environment and its created political context.

On the other hand, the nature of the castle as a phenomenon with a complex structure is emphasised, and, as R. Koselleck aptly described: 'events can only be related, structures can only be described' 54 . In the latter case, there is a clear distinction between the strategy of a methodological 'event' and the 'structure' of research. The first is explained by the fact that the event is 'triggered' by certain specific subjects, while structures are more than individual and intersubjective. Therefore, one cannot reduce their explanation to the actions of distinct individuals or groups. On the other hand, the very structures are palpable only in their relation to the events in which they are articulated and identified ${ }^{55}$. In this way, the castle can be understood as a phenomenon, and as a certain long-term structure in a specific territory with just its characteristic development and transformations.

In particular, it is necessary to distinguish the (structural) terms of the investigated problem. The castle phenomenon can only be adequately explained in a pluralistic perspective, and in a shared connection with the various phenomena of the social reality. The castle itself contained the structurally complex and difficult to reconstruct territorial and social framework of that period. The main task of structural history on this subject is to try to evaluate integrally every segment of the social reality, which had or may have contributed to the development of the castle and its changes. It is necessary to emphasize the fact that certain distinctions within the investigated phenomenon are conditional, because they are closely linked with each other. Therefore, often when explaining one aspect (e.g. social), the latter is interpreted only by also touching on another (e.g. legal). Therefore, looking from the aspect of methodological work, repetition is inevitable. Trying to be more specific, one can distinguish several main aspects.

54 R. Koselleck, Vergangene Zukunft. Zur Semantik geschichtlicher Zeiten (Frankfurt am Main, 1989), p. 144.

${ }^{55}$ Ibid., pp. 147-150. 
The legal aspect (a). This is the building of a castle or any other associated (permit, insurance, penalties) regulation, i.e. the issue of castle building and its control regalia. First of all, examples from Western Europe, which point to the existence of a prohibition to build private castles ${ }^{56}$, or at least that the arbitrary construction of a castle would result in sanctions ${ }^{57}$, imply the raising of this issue. Moreover, the very construction of a castle had to be authorised by the privilege/authorisation of the sovereign. Meanwhile, privileges granted to the nobles of the GDL, giving the right to build a private castle, can be detected only from the turn of the 15th and 16th centuries. In this case, it is necessary to discuss separately this late phenomenon of granting the right of the 'regalia transfer' of a castle.

The second level of the legal element is perceived as a clash of different local jurisdictions. Here is the problem of the city and castle having different judicial territories (with unclear borders), and of the individuals subordinate to them. Sources allow this to be grasped only in the first half of the 16 th century ${ }^{58}$, and signal

${ }^{56}$ Indicated relying on the body of law of (a) Normandy, (b) Saxon mirror, (c) Swabian mirror and (d) Austrian land: (a) [...] nulli licuit in Normannia castellum facere [...], (b) [...] Man en muz ouch keine burg bowen noch stat vestenen mit planken noch mit muren [...], (c) [...] Man sol oh deheine burc buwen noh dorfer veste machen noh berge mit vestenunge ane des lantrihtaer urlaup [...], (d) [...] So ensol auch niemant dhain haus noch purg pauen an des landesherren gunst und an sein urlaub [...]; cited according to U. Albrecht, Der Adelssitz im Mittelalter. Studien zum Verhältnis von Architektur und Lebensform in Nord- und Westeuropa (München-Berlin, 1995), p. 36; E. Schrader, Das Befestigungsrecht in Deutschland von den Anfängen bis zum Beginn des 14. Jahrhunderts (Göttingen, 1909). About the law on the construction of defensive fortifications as regalia and its granting, see A. Coulin, Befestigungshoheit und Befestigungsrecht (Leipzig, 1911).

${ }^{57}$ The first penalty mentioned in written sources for the illegal construction of a castle is known from the Edictum Pistense capitulary of Charles II the Bald in 864, see Monvmenta Germaniae Historica, Legvm Sectio II. Capitvlaria Regvm Francorvm, T. II (Hanover, 1897), p. 328: [...] ut, quicumque istis temporibus castella et firmitates et haias sine nostro verbo fecerint, Kalendis Augusti omnes tales firmitates disfactas habeant; quia vicini et circummanentes exinde multas depraedationes et impendimenta sustinent. Et qui eas disfacere non voluerint, comites, in quorum comitatibus factae sunt, eas disfaciant [...].

${ }^{58}$ See the historiography devoted to GDL cities: Z. Kiaupa, Kauno istorija (Vilnius, 2010); also the series of sources on Lithuania's Magdeburg cities, Lietuvos magdeburginiu miestu privilegijos ir aktai (1991-2010). About the being formed legal aspect of the Magdeburg city (and with the literature shown in the article), see J. Karpavičienè, 'Magdeburgo teisè: ištakos ir transformacijos', Lietuvos miestu istorijos šaltiniai, 3 (2001), pp. 175-250. Lietuvos Metrika, Užrašymu knyga 25 (1387-1546), p. 102: [...] А далеи старосте на замъку нашомъ судити княскихъ и паньскихъ и земяньскихъ людеи [...]; Русская Историческая Библіотека, 
that the subordination of the intertwined territories and different social categories was the daily reality of the society of that period.

The political (b) moment of the role of the castle. According to H. Ebner: 'The greater part of medieval politics was the politics of the castles. The battle in war and disputes was the battle for castles and fortified cities. The castle was the point of attack and the instrument for the tactics of military delay ${ }^{59}$. The most notable instances of succession and/or the attempt to establish the latter, which are associated with the castle, are considered to be the struggle between Švitrigaila and Žygimantas Kęstutaitis for power in the GDL in the 1430s, and the dispute between Lithuania and Poland over the territories of Podolia and Volhynia and the castles located in them. Jan Długosz clarifies the last conflict quite broadly ${ }^{60}$. No less important was the war between the Teutonic Order and the Grand Duchy, where the struggle was, inter alia, for castles. In any case, the castle in these conflicts appears as the main lever for establishing authority. One can also recall the assumption already raised in historiography on the construction of the Kreva, Lyda and

т. XX: Литовская Метрика, т. I (Петербургъ, 1903), рp. 602-603: [...] жаловали намь мешчане Меньскии на наместника Менского князя Богдана Ивановича [...] Приказали князю Богдану: итожь онъ черезъ то не маетъ ихъ ни судити, ани рядити, и децкихъ на нихъ не давати [...] маютъ они права своего Маитбарского вжывати, и справоватися, подлугъ права своего [...]; pp. 837-838; in 1502 the conflict of the Polotsk city residents with the viceregent of Grand Duke Stanislovas Glebavičius [...] Ино намъ ся видело и патомь раде нашой, штожь замку нашому Полоџъкому шкодно и наместникъ нашь прысудовъ никоторыхъ не маеть, и для того прыдали есмо пану Станиславу въ городскии присудъ сельскихъ путниковъ. А наместнику [...] того права не [...] не рушити [...]. Lietuvos Metrika, Užrašymu knyga 15 (1528-1538), ed. A. Dubonis (Vilnius, 2002), pp. 130-132; in 1531 the conflict of the city of Kaunas with the sovereign's officials: [...] и улииу деи, которая здавъна была у присуде замъковомъ [...] абыхмо тую пущу и перевоз на Немъне казали тобе прывернути къ тому замъку нашому [...]их перевоз тежъ отънял в нихъ, и прывернуль къ замъку нашому [...] И тую улииу, з домы и з мещаны, которую еси къ замку намому был прывернуль, и перевозъ на Немъне къ месту на себе теж мети, и мость на реие Еси, и тое именье, которое они купили у князя Мхаила Глиньского со въсими людми и земълями къ своим рукамъ держати водле привилевъ предковъ нашихъ и нашых [...].

${ }^{59} \mathrm{H}$. Ebner, 'Die Burg als Forschungsproblem mittelalterlicher Verfassungsgeschichte', Die Burgen im deutschen Sprachraum. Ihre rechts- und verfassungsgeschichtliche Bedeutung, T. I, ed. H. Patze (Sigmaringen, 1976), p. 11.

${ }^{60}$ J. Długossii, Opera omnia, t. IV (Cracoviae, 1877), p. 198: Et licet castrum Kyow obsidione cinxiset et eius obsidionem aliquanto tempore continuasset [...]; t. III, pp. 560-561: Podoliae terram et castra Wladislaus Rex recuperat et suas eis praeficit $[\ldots] ;[. .$.$] ad castrum Kamyenyecz expugnandum operam novat, bom-$ bardisque illud qualit [...]; t. V, pp. 90, 102, 107, 115. 
Medininkai castles in 1377-1382 during the dynastic struggles for the throne of the Grand Duchy ${ }^{61}$. The list made by the Teutonic Order in 1432 of the territories (castles) under Švitrigaila ${ }^{62}$, in which the Ruthenian territories, their cities and castles, belonging to the Algirdaičiai are written down could be seen as a complement to these examples. From this list, the manner in which the territorial government is perceived and defined becomes clear (in this case, it does not matter how much it matched the actual situation of the period). It is worth stressing here the fact that under such conditions, the dependence of certain areas and the castles located in them was extremely volatile and uncertain.

One can further mention the castle's military-defensive function (c), which, being essentially the primary cause for the emergence of the castle in Western Europe ${ }^{63}$, often 'overshadows' the whole complexity of the castle phenomenon. The situation in the GDL is interesting, because in its different territories (lands) at various times, castles carried out an unequal military-defensive role (for example, attention is paid to 14th-century Žemaitija or Lithuania propria and in the first half of the 16th century the border between the Ruthenian lands and the state of Moscow and the Tatars and the functions of the castles, about which the material of the seimai (parliament) and

${ }^{61} \mathrm{~K}$. Mekas, A. Žalnierius, 'Medininkų pilies archeologiniai tyrinèjimai 1961-1963 metais', Lietuvos archeologija, 28 (2005), p. 159. Trying to visualise better the nature of such conflicts and the importance of the castle in them, a representative example in this case would be the conflict in the 1380s between two noble families of Greater Poland: Grzymalitów z Nałęczami... Based on this dispute, the Polish historian Leszek Kajzer makes the assumption about certain changed socio-political circumstances, and the arising of a new situation in the development of the formation of private castles. The historian likewise comes to the conclusion that perhaps this conflict reflects the upsurge of the importance of the castle as a practical and symbolic representative at the end of the 14th century in Poland's society. Thus, a socio-political conjuncture is also introduced into the explanation of the concept of the castle; see L. Kajzer, 'Małe czy duże, czyli o tzw. zamkach rycerskich na Niżu Polskim', Zamki i przestrzeń społeczna w Europie środkowej $i$ wschodniej (Warsaw, 2002), p. 113.

${ }^{62}$ Berlin-Dahlem Geheimes Staatsarchiv Preussischer Kulturbesitz, XX. Hauptabteilung (Königsberger Archiv), Ordensbriefarchiv, No. 27885; [...] Nomina civitatum castrorum et districtuum quos possidet Swidrigall [...]. The document was published in: Skarbiec diplomatów papiezkich, cesarskich, krolewskich, ksiązęcych, ed. I. Daniłowicz, t. I (Vilnius, 1860), pp. 330-331.

${ }^{63}$ T.N. Bisson, 'The Feudal Revolution', Past and Present, 142 (Feb. 1994), pp. 12, 15; G. Duby, 'The Diffusion of Cultural Patterns in Feudal Society', Past and Present, 39 (Apr. 1968), p. 7. 
inventories of the castles testify). The military-defence importance of the castle was more important, as it helps to clarify the changes in the castle's functions, depending on the prevailing situation in a particular part of the GDL. In this way, the change of function implies the structural transformations of the castle itself, i.e. the castle turning into a manor (Eišiškès, Punia, Kernavè, Alytus etc) and/or a certain territorial-administrative unit. As an example, here one can invoke the structure of the district (pavietas) that appeared after 1564-1566. With the latter issue, one can raise the question of the territorial continuity between the castle, its territories and the newly formed territorial, judicial and administrative structure of the districts.

The mentions in the Order's chronicles mentioning the horse stud farms in densely populated areas and the grain stored in the castles testify to the castle's economic nature (d). The privileges of the Church appearing at the end of the 14th century unequivocally testify to the (economic) integrity and the internal relationships coupling the castle and its territories, i.e. territorial dependence and the resulting obligation system, which provided the material foundation of the castle ${ }^{64}$.

There is also a submitted example reflecting another aspect of the social phenomenon in question. Jogaila in 1387 bestowed the Tauragnai castle and its territory and villages to the Diocese of Vilnius ${ }^{65}$. In turn, Vytautas in 1429 donated to the Church the Czarnokosnycze castle and town in the Podolia lands ${ }^{66}$. These two examples, to our

${ }^{64}$ Certain tributes or parts of them belonging to the Church reveal the nature of the castle as a certain 'local' economic realisation mechanism, see Kodeks dyplomatyczny Katedry i diecezji Wileńskiej, T. 1 (1387-1507), $(K D K D W)$, ed. J. Fijałek, W. Semkowicz (Cracow, 1948), p. 31; in 1390 two talents (one talent is about 26 kilos) of wax from the sovereign's manor in the Vilnius castle, p. 52; in 1397 from the Vilnius castles and its cellars (eius cellariis) were given ten decks of honey (decem pullis mellis), p. 93; the 1415 privilege of Vytautas, which obligated the Old Trakai castle each year to give a tenth of all fruits (decimas omnium frugum) with oats and hay (cum avena et feno).

${ }^{65}$ Ibid., pp. 4-6: [...] incorporamus et donamus donacione perpetua [...] ecclesie et ipsius episcopo [...] castrum nostrum Turogno cum districtu eidem adiacente et villis Lobonari ac Moletani, necnon districtum Dombrowno [...].

${ }^{66}$ Vitoldiana, Codex privilegiorum Vitoldi Magni Ducis Lithuaniae 1386-1430 (Viltoldiana), ed. J. Ochmański (Warsaw-Poznań 1986), pp. 206-207. 
knowledge, are isolated cases, when a castle was bestowed to the Church, and this is particularly contrasted with the situation which characterised Western ${ }^{67}$ and also Central Eastern Europe. In many cases in these regions, a castle was an object at the disposition of the Church, i.e. it belonged directly to the Church's structure as an institution of land tenure. This episode provides an opportunity to assume that the GDL's clergy did not develop structures that would have allowed them to 'confront' (as was common in Western Europe) the lay nobility. The examples of neighbouring countries ${ }^{68}$, both Poland and territories of the Teutonic Order, Prussia and Livonia, perfectly illustrate the scale of the Church's relationship with the castle. Therefore, it is necessary to raise the question untouched up to now in historiography of the relationship between the Church and the castle: what was the relationship between the Church and the castle in the GDL? This way we gradually approach what might be called social history, i.e. the movement from structures to social groups of society and their relationships in the discussed structures.

From the point of view social history (e), the most interesting thing is the question of the genesis of the nobility's castle. In West-

${ }^{67}$ The example of the castle policies and consolidation of authority carried out by Archbishop Balduin of Trier could be symptomatic; see W.-R. Berns, Burgenpolitik und Herrschaft des Erzbischofs Balduin von Trier (1307-1354) (Sigmaringen, 1980).

${ }^{68} \mathrm{It}$ is obvious that since the second half of the 13th century the castle in Livonia had become the object of permanent discussion/dispute between the Order and the bishop or chapter, see Liv-, Esth- und Curländisches Urkundenbuch nebst Regesten, ed. F.G. von Bunge, Bd. 2, (1301-1367) (Reval, 1855). Here is one relation of the dispute in 1366 between the Riga Archbishop and the Teutonic Order, in which among the multitude of the objects of conflict, the questions of the construction, dependence and rule of castles are discussed: p. 755: und ander husere, di gebuwet worin czu rentin den brudern [...]; p. 763: Abir das hus, genant Ikeskulle, haldin die brudere bekummert, das da gehorit czu dem erczebischoffe, das bittet der erczebischof im ouch wedir czugeben [...]. Liv-, Esth- und Curländisches Urkundenbuch nebst Regesten, ed. F.G. von Bunge, Bd. 3 (1368-1393) (Reval, 1857). In 1271 the Riga chapter, residing in the Tervete castle (magister et fratres castrum Therwetene) transfers the Dobene and Sparnene castles to the Order: p. 69; [...] Dobene scilicet aut Sparnene, cum terminis suis, conferimus fratribus antedictis [...]. Poland's examples in which the interest of the bishops to build is reflected: L. Kajzer, 'Z problematyki badań zamków biskupskich w Polsce Średniowiecznej', Siedziby biskupów krakowskich na terenie dawnewgo województwa sandomirskiego, Materiaty z sesji naukowej Kielce 20 IX 1997 (Kielce, 1997), pp. 7-14; idem., Zamki i społeczeństwo. Przemiany archtiktury i budownictwa obronnego w Polsce w X-XVIII wieku (Łódź, 1993), pp. 143-144. 
ern Europe, the castle was one of the main aspects of the nobility's self-awareness and self-promotion: the means of expession of origin, government and continuity. However, the question remains absolutely open for the GDL's nobility and its castles. The key aspect of the latter problem associated with this social category is the attempt to clarify the nature of their relationship with the castle and its place in the rapidly expanding land tenure structure. On the other hand, in the relations btween the castle and the nobility, one can encounter one of the notations which might explain (at least from one perspective) the extremely difficult to grasp phenomenon of mental self-awareness. The castle appears in the spotlight of the nobility's interest, and arises as a kind of symbolic expression of direct power. In Western Europe, this phenomenon began to emerge in the tenth to 13th centuries, when the nobility began to associate themselves with a particular origin (patrimonial) location, in which usually at the time of feudal fragmentation, or, in the words of T.N. Bisson, feudal revolution, the castle emerged. Thus, the territory in which the noble's castle stood, and the rise of the inherited name, were directly interrelated ${ }^{69}$. In the case of the GDL, we can also find similar, but much later clues, but they are relatively random, and it would be quite problematic to associate them with a particular castle. By the beginning of the 16th century, the sources did not explicitly link the nobility with a castle, for example, in the Wegebericht only the nobility's estates and villages are mentioned.

The inventories of castles, evaluated together from the point of view of social history that appeared at the end of the 15th century, often interested only economic or economics historians. However, this group of sources can also provide a considerable amount of information about the social configuration of the castle's space: membership in a particular jurisdiction, the contingent of the social categories in the castle, and in general the concept of the inner territory of the 16th-century castle, whose primary hypothesis could

${ }^{69}$ L. Figueras, 'Personal Naming and Structures of Kinship in the Medieval Spanish Peasantry', Personal Names Studies of Medieval Europe: Social Identity and Familial Structures (Kalamazoo, Michigan, 2002), p. 63. Examples are provided of the nobility of Catalonia and France, in which in certain cases a castle would be assigned to a younger son, who would take over its name instead of the father or the brother, and thus gave a start to a second branch of his family under a different name. 
be formulated by explaining the territory of the castle area that existed as an unequally distributed internal structure supported by the dependence of a variety of dispersed settlements. At the same time, it is a very useful resource when trying to look at the lower layer of society (associated with the castle, serving it) and its internal stratification. Ultimately, a promising test would be, while comparing the inventory material of various castles, to define the specifics of one from other spatially remote GDL local societies ${ }^{70}$.

Attention is paid to several other aspects of the (space-regional, social fabric) directly related to the research of castle structures and in the context of social history. First of all, chronologically, the castle in Lithuania in the narrow sense (Lithuania propria) and Žemaitija was a late phenomenon (the issue in the GDL's Ruthenian lands is a separate question $)^{71}$. According to the data of early sources, the possession of castles by the nobility is unclear because the sources are uninformative. The question of the nobility's interface with the castle remains open. Two variants for solving this problem are most justified. First, it is likely that the ruler only slowly and gradually reserved the exclusive right to construction of a castle ${ }^{72}$. Second, for the nobility generally, the castle was not characteristic of the expression of their status and power (the question of the 13th-century castles of the Baltic tribal nobility remains open). The earliest case we know when a nobleman's

70 Attention is drawn to the large volume of the surviving inventory of the Orsha and Rodoshkovich castles from the middle of the 16th century in which are listed in detail the territories belonging to the castles and their social categories (service people), accountable to the castles: Dokumenty moskovskago arkhiva ministerstva iustitsii, т. I (Moscow, 1897), pp. 90-119, 123-39. No less interesting are the revisions conducted in 1545 in the GDL southern lands of the Kremenets, Lutsk, Vinnitsa, Bratslav and Vladimir castles; see Litovs'ka Metrika, Kniga 561, Revizii Ukrains 'kikh zamkiv 1545 roku, ed. V. Kravchenko (Kiev, 2005), pp. 99-254. Also detailed descriptions carried out in 1552 of the castles of Cherkasy, Kanev, Kiev, Chernobyl, Ostersko (between Kiev and Chernigov), Vinnitsa and Mozyr; see Arkhiv' Iugo-Zapadnoi Rossii, ch. VII, T. I (Kiev, 1886), pp. 76-123, 587-628.

${ }^{71}$ About this, to form an overall picture of the problems, see S. Brather, Archäologie der westlichen Slawen: Siedlung, Wirtschaft und Gesellschaft im frühund hochmittelalterlichen Ostmitteleuropa (Berlin-New York, 2001), pp. 122-126; on Kievan Rus' castle questions, which are directly related to the GDL attached territories, see Drevniaia Rus : Gorod, zamok', selo (Moscow, 1985), pp. 94-96.

${ }^{72}$ R. Petrauskas, 'Socialiniai pokyčiai Lietuvoje valstybès formavimosi laikotarpiu', Lietuvos valstybès susikūrimas europiniame kontekste, comp. by R. Petrauskas (Vilnius, 2008), pp. 177-181. 
castle is mentioned is from the end of the 14 th century ${ }^{73}$, while this was a social reality in Western Europe in the 12 th and 13 th centuries ${ }^{74}$.

In general, the problem of castle dependency/subordination should be posed and resolved in the context of the discontinuity of GDL territory and the directly related social heterogeneity of local societies. Here, it is necessary to take into account the nature of the dependence of the very GDL-formed territories and the resulting status of the castle. On the other hand, the identification of the situation is also made more difficult by the local rulers, i.e. old Rurikids or Gediminids 'sitting still' in Ruthenian territories during the policies carried out by Gediminas. There are some possible examples, such as Podolia of the Karijotaičiai, of Volhynia of Švitrigaila. So at this point, we inevitably encounter the problems of the status and power of the social apex (knights, nobility) of different territories. In such a case, one could look at the state centralisation policy carried out by Vytautas. Finally, one could try to clarify the other structural differences between the castles of various state lands.

\section{A model for researching the phenomenon of the castle}

In attempting to investigate castles in the GDL, the essential problem is the heterogeneity of its external (extra-macro) territory, and thus also of its society. However, this feature is common to all ancien régime societies. This implies the precedence of the comparative method when trying to reconstruct the specifics of the structure of society or its expressions.

For the definition of the castle as an object of investigating structures and social history, one should briefly mark out the ter-

${ }^{73}$ For the case of Dirsūnai castle; see Cronica nova Prutenica, Scriptores rerum prussicarum, Bd. 2 (Leipzig, 1863), p. 572: intrant terram Dirsunen [...] castrum etiam Dirsunen vicerunt [...]. R. Petrauskas identifies this as a possible interpersonal oral agreement between the sovereign and a nobleman, strengthening loyalty and trust, see Petrauskas, Socialiniai pokyčiai, p. 181. In assessing this case, attention should also be paid to its location, i.e. it is on the very borders of the GDL and the so-called wasteland (Wildnis).

${ }^{74} \mathrm{U}$. Albrecht, Adelsitz. The whole latter book discusses the emergence of the castle and the change of the nobility's relationship with it from the first appearance of castles until the 'degradation' of the castle as a phenomenon. In an encyclopaedically brief way, issues of the typology of the castle are discussed. There is also a separate directory type work of one of most famous scholars of Czech castles that discusses the chronology of the emergence of castles in the Czech Republic, the beginning of which dates back to the 13th century and the typology of castles, see. T. Durdík, Encyklopedie českých hradů (Prague, 1999), pp. 15-23. 
ritorial concept of the castle. The castle 'was carrying' with itself information of a multifactor content. Meanwhile, the territory of the castle area can also be interpreted ambiguously: judicial accountability, administrative dependence, systems of economic and military obligations, etc. All of these are the main aspects of the content of the castle's constituted territory. Therefore, one can ask: how is the model of the castle reconstructed as a unit structuring space and likewise forming a territory?

In Lithuanian historiography, after a long break, a new effort appeared to formulate the conception of the territory of the GDL ${ }^{75}$ and its simultaneous reflection ${ }^{76}$ as well as the problems directly flowing from it and the methods of their resolution. However, the latter investigations are related more to the problems of the state's external borders and its limited territories. In our case, the reconstruction of the GDL space is important (the determination of the approximate spread of castles in the state), and namely the identification of the significance of the castle as a territorial-structural unit.

Understanding the castle as a spatial structure, one has to distinguish its internal (intra-micro) and external (extra-macro) territories. The first is defined as the area bounded by the walls of the castle. The second is the other side of these walls, and its territory does not have specific milestones marking it. Sources describe the first succinctly, but clearly ' [...] ecclesiam castro nostro Vilnensi constructam et locatam [...] ${ }^{77}$. With regard to Ruthenian castles, the same formula applies ${ }^{78}$. The exterior territory of the castle, not having materially obvious links, is described much more abstractly:

${ }^{75}$ L. Bucevičiūtè, Lietuvos Didžioji Kunigaikštystė XV-XVI a.: valstybès erdvès ir jos sienu samprata. Doctoral dissertation (Kaunas, 2010). In general, about the variabilities and unclarities/unsettlements of the state and its borders in the Middle Ages, see E. Schubert, Fürsterliche Herrschaft und Territorium im späten Mittelalter (Munich, 2006), pp. 1-5.

${ }^{76}$ T. Čelkis, 'Nuo teritorinio ruožo prie linijos: sienų sampratos pokyčiai Lietuvos Didžiojoje Kunigaikštysteje XIV-XVI amžiuje', Lietuvos istorijos studijos, 22 (2008), pp. 58-73; idem, Valdžia ir erdvè: Lietuvos Didžiosios Kunigaikštystès teritorializacijos procesas XIV-XVI a. Doctoral dissertation (Vilnius, 2011).

${ }^{77} \mathrm{KDKDW}$, pp. 4, 48; 58-59; p. 197. Lites ac res gestae inter Polonos Ordinemque Cruciferorum, (Posnaniae, 1855), p. 152.

${ }^{78} \mathrm{KDKDW}$, p. 674, The case of Vitebsk: Item curia seu domus penes ecclesiam in inferiori castro ex antiquo cum toto eius sittu et area [...]. Respectively the cases of the Lutsk and Smolensk castles, see Lietuvos Metrika, Užrašymu knyga 8 (1499-1514), ed. A. Baliulis, R. Firkovičius, D. Antanavičius (Vilnius, 1995), pp. $256 ; 316-317$. 
'[...] intrantes terram Lethowie castrum dictum Bisenam [...] reliqua pars exercitus intravit dicti castri territorium [... $]^{79}$. Thus, the existence of the distinctions in the very territory of the castle should be designed together also in the arising of different social and job position mechanisms, the development of which in the early 14th to 15 th centuries is characterised by fundamental transformation.

In this way, the contextualisation of the castle is necessary in the plane of different societies and its created phenomena. As a result, the differentiation of the layers and the perspectives of the research of the layers of the very castle's problems diverge. We will discuss further the cuts of the research.

The castle and inner territory At this level of investigation, the most important attention is concentrated on a specific object. Not undertaking a separate analysis of all known castles, representative cases of castles were distinguished, revealing the structural changes that took place. One can mention here the examples of the Veliuona, Kernavè and Trakai castles, which allowed the reconstruction of local structures and the features of their social contingent as the sociopolitical circumstances changed. Veliuona Castle carried out defensive functions directly, but after losing its strategic importance after the Battle of Grünwald, it gradually turned into a manor of the Grand Duke. On the other hand, even after losing its original functions, Veliuona, in the further conflict that took place between Vytautas and the Teutonic Order in the 1410s, remains an important object of dispute ${ }^{80}$. The case of Kernave Castle is distinguished by the

${ }^{79}$ Peter von Dusburg, Cronica terre Prussie, Bd. 1, Scriptores rerum prussicarum, (Leipzig, 1861), p. 147. Also see $K D K D W$, pp. 44; 208; 477. Lites ac res gestae inter Polonos Ordinemque Cruciferorum, t. II (Poznań, 1892), p. 137: [...] quod castrum Veluna ac predium et territorium ipsius castri fuit et est fundatum [...] subiecta inter villas prescriptas in primo articulo et quasi centro earundem villarum et territorii ipsarum [...]. Basically, in defining the external territory of the castle, both in the first half of the 15th century as well as in the 16th century, the same well-established form was used (castrum cum omnibus et singulis curiis, districtibus etc.); see CEV, p. 794. Opisanie rukopisnogo otdeleniia Vilnenskoi publichnoi biblioteki, т. III (Vil'na, 1898), pp. 50; 51. Gudavičius raised and based the idea of the castles and their formed regions (territories), see Gudavičius, 'Lietuvos pašauktinès kariuomenès', pp. 52-53; idem, 'Lietuvos valstybès struktūra', p. 139.

${ }^{80} C E V$, p. 259. Here is one of the complaints of the grand master to Sigismund of Luxembourg about the 'activities' of Vytautas in Veliuona. It states that the Veliuona castle is not built in Žemaitija territory and that it has to be returned to the Teutonic Order: [...] Das huws czu Welune, das in des ordens grenczen ist gebuwet wol sechs meilen [...] das dasselbe hus Welune nicht lit lande Samaythen, 
fact that after the internal fights that occurred at the end of the 14th century, the castles were not restored, even though they belonged to Lithuania propria, the territory where the main domain holdings of the Grand Duke were. The castles of Kernave remained unrestored, although at least from the 13th century the area was distinguished by its developed internal topography and social structures ${ }^{81}$. The case of Trakai is interesting, as how in a compact territory a complex of castles was formed with the individual castles having different fates. The castles of Old Trakai, of the Trakai peninsula and of the Trakai island built by Vytautas at the beginning of the 15th century are an example of the formation of a dynastic centre ${ }^{82}$. However, after the ruling dynasty changed from the middle of the 15th century, Trakai became a hunting lodge of Kazimieras Jogailaitis, although in 1450 (1451?) and 1477 the Venetian ambassadors Josaphat Barbaro and Ambrosio Contarini visited it, and in 1483 in Trakai a meeting between Kazimieras Jogailaitis and the Grand Master of the Teutonic Order Martyn von Truchsess took place ${ }^{83}$. Meanwhile, from the first half of the 16th century, the two castles of Trakai became prisons ${ }^{84}$.

\section{The castle created exterior territories and structures As one} could have been convinced earlier the territory of the castle was not only what the castle walls encompassed. The early fragmentary sources allow one to understand the castle beyond (extra-macro) the territory restricted by the walls. Sources in the 14th and early 15 th century provide the possibility to define the territory at least

das her sich nichte wil vorczeien noch obirgeben [...]. In another letter in 1413 to Sigismund of Luxembourg, the Grand Master complained that a year ago Vytautas built a castle in Veliuona and strengthened the defence of the frontier: ibid., p. 263: lit in der buwunge des huwzes Welun, das her vor eine ior hat ofgerichtet. Ouch so hat er alle den sinen ussgeboten; dorczu so hat her mit den sinen des ordens grenczen vaste bestalt [...].

${ }^{81}$ Gudavičius, Miestu atsiradimas, pp. 55-63; G. Vèlius, Kernavès miesto bendruomene XIII-XIV amžiuje (Vilnius, 2005).

${ }^{82}$ P. Klimas, Ghillebert de Lannoy in Medieval Lithuania (New York, 1945), pp. 46-48. For more information about the construction of the Trakai island castle, see Ivinskis, 'Trakų Galvès', pp. 135-198.

${ }^{83}$ S.C. Rowell, 'Trumpos akimirkos iš Kazimiero Jogailaičio dvaro: neeilinè kasdienybè tarnauja valstybei', Lietuvos istorijos metraštis, 2004/1 (2005), pp. 25-56, see also the supplement; pp. 51-55; Barbaro i Kontarini o Rossiii. K istorii italo-russkikh sviazei v XV v., ed. E.C. Skrzhinskaia (Leningrad, 1971), pp. 159-160, pp. 232-234.

${ }^{84}$ Lietuvos Metrika, Irašu knyga 11 (1518-1523), ed. A. Dubonis (Vilnius, 1997), pp. 87-88. 
hypothetically. In 1428, the writing down of the Novgorodok lands and castle by Vytautas for his wife can be one of the few such. In this document, the words Novgorodok land (terram) and the castle (castrumque) with all the Novgorodok territory (cum toto districtu) and all the other villages and estates (cum omnibus aliis villis et curiis), are named: Nowesiolo, which is also called Kubarka, also Horodeczna, Bretena, Bassyno, Puolbreha, Dolaticze, Lubcz, Ostaschino, Niehniewicze, Polonaia, Korelicze, Swerszno, Cyrma, Polamka, Poczapow, Lachowo and Buobr ${ }^{85}$. The exterior territory of the castle is much clearer, i.e. one can reconstruct the territories (villages, estates with their social contingent) directly subordinate to it on the basis of the already mentioned 16th-century inventories of the castles.

\section{The specifics of the land's (regional) castles (the features of the castles of the lands/districts comprising the country) The} 'complex' of castles in Lithuania propria should be evaluated in a qualitatively new way. The question should also be raised about the castle structures in the lands of the $\mathrm{LDK}^{86}$, forming at the same time not only the defensive space, but also a certain communications/

${ }^{85}$ CEV, p. 794.

${ }^{86}$ Sources (the case of the Severo-Novgorod land) reveal the existence of such a network and its undoubted perception; see O. Rusina, Siverc'ka zemlia u skladi Velikogo kniazivstva litovs'kogo, Dodatok (Kiev, 1998), pp. 207-213. Cf. In the Ipat'evskaya Chronicle in 1159 the cities/castles forming the core of the Chernigov land are mentioned: Polnoe sobranie russkikh letopisei, t. 2: Ipat'evskaia letopis' (Moscow, 1962), p. 500: [...] Chernigov's' z 7 gorod' pust'y"kh Moroviesk' Liubesk' Orgosh'Vsevolozh' a v' nekh' sediat' psareve zhe i Polobtsi a vsiu volost' Chernigovskuiu soboiu derzhit' [...]; also see A.V. Sheshkov, 'Lichnoe kniazhskoe zemlevladenie v gosydarstvennoi strukture Chernigovskogo kniazhestva XII-pervshchi treti XIII v.', Pamiats'stagoddziau na kartse Aichyny (Minsk, 2007), pp. 104-134. In general, it is emphasised that the subordination and relationship of these lands with the state's core varied very greatly. Here is the vassal oath sworn by Fyodor Liubart in 1393 for the same Severo-Novgorod land that he ruled: Akta unji Polski z Litwa 1385-1791, ed. S. Kutrzeba, W. Semkowicz (Kraków, 1932). Attention is drawn to the text of the oath, although the latter in most cases, only an adaptation of the usual formulation: p. 31: terram suam Severiensem cum omnibus castris, fortalitiis, oppidis, villis, praediis, allodiis [...]. Also a not preserved donation from the beginning of the 15th century, which Jan Dlugosz mentions; see Vitoldiana, p. 63: castris Bransko et Starodub, quae ex Wladislai Poloniae regis et Alexandri magni ducis Lithuaniae donatione in Lithuania obtinebat [...]. Z. Norkus poses anew the question of the GDL territorial framework, i.e. the relations of the metropolis and the periphery: Z. Norkus, Nepasiskelbusioji imperija. Lietuvos Didžioji Kunigaikštija lyginamosios istorinès imperiju sociologijos požiūriu (Vilnius, 2009), pp. 262-277. 
authority consolidation network. One can call the already-mentioned article by Nikžentaitis about the defensive system of the castles on the Nemunas and Jūra rivers a similar kind of study. At the same time, the emerging castles of the nobility and their relationship with other land tenure structures (estates, villages, towns) owned by a particular nobleman are evaluated here. One can find the embryos of such a study in Polish historiography, which focuses on the specifics of the development of castles in the lands making up the Kingdom of Poland or later becoming integral parts of the state. One of the tasks raised was on the basis of data in the acts of the Lithuania Metrics which mentioned specific objects in one place to identify the structures of the land's (regional) specific castles, and their relationship to their surrounding territories. It is essential to stress here processes occurring in various areas not at the same time.

The spread of castles in the territory of the state All three of the above research strategies mentioned earlier can be consolidated into the common level of GDL territory, which would reflect the number of castles and their change, the distribution ratio of the state's territory and density, in the comparable context of Central and Eastern Europe. In this way, the full network of castles covering the GDL, and the territorial structure formed on its basis, would consistently reveal itself. The raising of this question is encouraged by the fact that historiography has not attempted systematically to collect data on GDL castles in certain periods.

In conclusion, one should note another distinction, which has been sporadically mentioned above, among the GDL lands and their castles. Here, spatial and social environment aspects intertwine. In this way, it is necessary to take into account the different prospects of the development of the GDL lands in the discussed period, i.e. the distinctions of the Ruthenian, Lithuania propria and Žemaitija castles. All of this would let one pose several research hypotheses that will allow the identification of differences between the castles of different lands and their social and spatial structures:

- Development of various castles in the GDL lands and the role of the castle in the discussed period differed depending on the geopolitical situation.

- The different subordination and status of the GDL lands, clearly revealing the campaign of homogial oaths at the end of the 14th c., implies exclusive status of the castle, depending on the specific land. 
- At the juncture of the 15th-16th c. the beginning to emerge geography of the nobility's castles expresses the ambiguous place of the lands comprising the GDL in the State, the different roles of localized societies and their peaks as well as the internal colonization and beneficial policy carried out by the Grand Duke from the end of 14th c.

- The internal policies carried out (e.g. the regulations for the sovereign's management of estates and castles in the first half of the 16 th century, the intensity of land reform in different GDL territories) and the change in the role and significance of the castle depending on specific GDL lands, could possibly have had a significant impact on the social contingent of the castles.

\section{Generalisation}

When trying to define the castle as a historical phenomenon, there are several essential aspects. In many cases, there is talk in historiography about the medieval castle as an architectural or defensive object. However, the castle, in particular, can be understood as the centre of a sovereign government and power, which emerged and evolved in a particular space and time. In the absence of stable centralised government administrative structures, the castle was almost the only reality helping to form and organise a governmentcreated space.

Therefore, the castle is valued as an integral part of a mechanism of territorialisation and government enforcement, with its characteristic social-duty apparatus. It formed a certain territory, and was its administrative centre, with an internal infrastructure and an economic service mechanism. The construction of medieval castles in Europe began at the end of the ninth century, while the more intensive period dates from the 12th and 13th century. In fact, the castle is a feature of the strengthening feudal political formations.

Talking about the castle as a phenomenon of medieval society, it is worth noting that this phenomenon took on asymmetrical forms in different regions of Europe, and in many places remained undeveloped. All this reflects the multifaceted nature of the castle, so there is no single universal definition of it. One can talk only about certain basic features that were characteristic of the castles 
of each region. In this sense, the castle should be understood as a constantly changing object, attaining new structural forms.

The definition of a castle by its content is ambiguous, and its conception and interpretation depends on the specifics of the investigation. Meanwhile, data from sources, being laconic, forces one to make assumptions not so specifically about the castle itself, which in the sources, depending on the language, is referred to in very different ways (castrum, arx, fortalitium hus, huszer, Zamek, городъ, городокъ), as to the territorial structure being formed with a relatively well-developed socio-topography and generally surrounding structures. Moreover, it is also essential to include in the definition of the castle its factor as a symbolic structure of medieval society. In this context, aspects of the castle as expressions of power and social status are important.

Therefore, the castle should be seen as a GDL social category from the early 14th to the 16th century, which was being formed in the context of the socio-political development of that time, but in parallel, it also influenced these processes. The newly built castle reflects the sovereign's attempt territorially, and also symbolically to reinforce his own power in a specific territory. We can speak about the rudiments of the castle phenomenon (we are not talking here about the genesis of the castle in Ruthenian GDL territory, which requires separate research) only from the turn of the 13th and 14th centuries, when the ruling dynasty, creating a new management tradition in Lithuania, gradually arose.

The castle is perceived as an object of structures (spatially) and social history (e.g. the nobility's castles, the social and job position contingent of the castle), whose field of research should cover various aspects of the social reality: judicial, military-defence, political-representative, economic. The quaternary model of castle research being formulated (1. a specific castle and its inner structure of test pattern; 2. the castle and its external structure; 3. specifics of the development of GDL lands castles; 4. the spread of castles in the territory of the state) implies a multi-layered perspective on the problem raised of the castle, going from the fact to the process, from the object to the structure. The article states that the castle as a long-term phenomenon cannot be understood and interpreted in isolation from the simultaneous socio-political circumstances and the shaping of their social environment. Therefore, in trying to 
understand the castle as a phenomenon of the whole GDL space, it is necessary to take into account many factors forming the state's social and structural heterogeneity. An important proviso is that there has not been a uniform trajectory in the development of the different GDL lands, and that determined directly the variations in the castle's development.

Author Details

Vytautas Volungevičius is a $\mathrm{PhD}$ student at Vilnius University, in the Faculty of History's Department of Ancient and Medieval History. His PhD thesis is 'The Castle and its Socio-political Transformations in the Grand Duchy of Lithuania in the 14th to Early 16th Century'.

Address: Vilnius University, Faculty of History, Department of Ancient and Medieval History, Universiteto 7, LT-01513 Vilnius

E-mail: vytautas.volungevicius@gmail.com

PILIS LIETUVOS DIDŽIOJOJE KUNIGAIKŠTYSTĖJE: ISTORIOGRAFIJA, DEFINICIJOS PAIEŠKOS, TYRIMO MODELIS

Santrauka

VYTAUTAS VOLUNGEVIČIUS

Autorius kelia pilies kaip reiškinio problemą Lietuvos Didžiosios Kunigaikštystès erdvejje, bandydamas į tyrimą ịtraukti visas ši darini sudariusias teritorijas: Lithuania propria, Žemaitiją, rusèniškąsias žemes. Straipsnyje visų pirma analizuojamos skirtingos pilies sampratos ịvairiakalbeje istoriografijoje. Antroje straipsnio dalyje nagrinėjama vienalaikių istorinių šaltinių terminija ir jų tendencijos. Prieinama prie išvados, kad viduramžių šaltinių terminai ne visada išreiškẻ egzistavusios istorinès socialinès tikrovès realią situaciją. Dažnai šaltinių terminija buvo automatiškai perkeliama iš vienos socialinès terpès kitai apibūdinti nerandant adekvataus atitikmens reiškiniui ar objektui ịvardinti. Trečioje straipsnio dalyje bandoma formuluoti teorinè pilies fenomeno tyrimo prieiga, pili interpretuojant kaip struktūrų ir socialinès istorijos objektą. Išskiriami penki pilies tyrimo sluoksniai: teisinis, politinis-reprezentacinis, karinis-gynybinis, ūkinis, socialinis (pvz., diduomenès pilių radimasis, pilies socialinè ir pareigybinè „,charakteristikos"). Ketvirtoje dalyje pateikiamas pilies tyrimo modelis, kuris grindžiamas keturnariu erdvės skaidymu i (1) pilies vidinę teritoriją, (2) pilies išorinę teritoriją, (3) LDK sudariusių žemių pilis, (4) pilių pasklidimą LDK erdvèje. Tokia 
tyrimo strategija, atsižvelgiant ị LDK teritorinị ir socialinị nevienalytiškumą, ịpareigoja judèti nuo fakto prie proceso, nuo objekto prie struktūros. Straipsnyje teigiama, kad pilis, kaip ilgos trukmès reiškinys, negali būti suvokiama atsietai nuo vykusių sociopolitinių procesų, kuriems įtakos turejo lokalios bendruomenės. 